\title{
Geneticists lay plans for rationalized rodents
}

\section{Alison Abbott, Munich}

Mouse geneticists in Europe have launched an initiative to standardize the flood of data being generated by studies of mouse mutants.

At a meeting in Paris last week, the heads of European mouse-genetics research centres agreed to unify the screening processes used to identify mouse mutants that may aid studies of human diseases.

The 17 members of EUMORPHIA the European Union Mouse Research for Public Health and Industrial Applications network - plan to use two levels of screens, and to make full descriptions of the mutants available on a public database.

"The first level would hopefully be

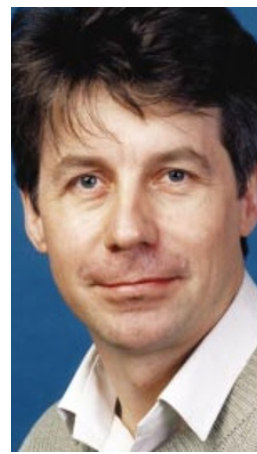

Steve Brown wants a two-pronged test for mutant mice. applied to all mutants," explains Steve Brown, director of the Medical Research Council's Mammalian Genetics Unit at Harwell, UK, and one of the two EUMORPHIA. "We'll design a fast series of tests to answer simple questions. Are the mice deaf? Are they overweight?" Second-level tests will then be used to take a more thorresearchers running

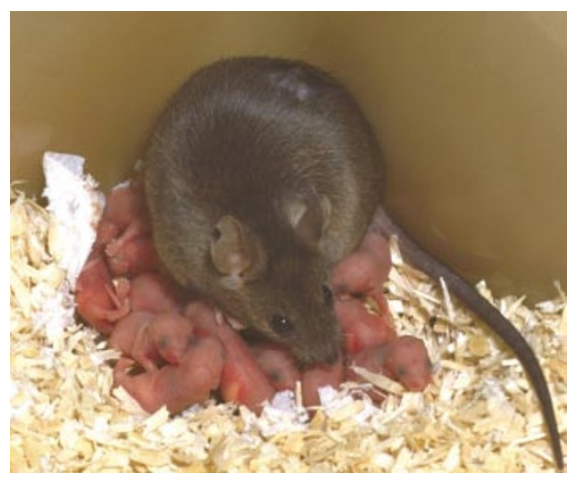

Screen star: standardized tests for mutant mice may speed up research into human diseases.

ough look at the unusual characteristics identified in the first screen.

In the past four years, hundreds of mouse mutants have been created by random chemical mutagenesis, in which chemicals are used to introduce a random mutation into the animal's genome. Researchers study the effect of the mutation and, if the resulting characteristics are interesting, identify the gene responsible.

Knockout mice, in which a specific gene is targeted and disabled, are also widely used to model and study human diseases. The rate at which both types of mutant are being created has been accelerating as the mouse genome sequence nears completion.
Two centres - the GSF national research centre in Munich and the Harwell unit have been screening mutants generated by chemical mutagenesis, and have already identified nearly 600 types that may be useful in disease studies.

Some of the standardized tests will be based on those already used at Munich and Harwell, with the task of defining the others being split between EUMORPHIA members. Experts from outside Europe will also be invited to participate, and EUMORPHIA members hope that the tests will soon be adopted globally.

Knockout mice could also be screened using the new tests, says Pierre Chambon, director of the Institute of Genetics and Molecular and Cellular Biology in Strasbourg, France, and the other EUMORPHIA leader.

This could be beneficial, he adds, recalling an incident when he discovered by chance a link between retinoic acid and the neurotransmitter dopamine. While studying developmental problems, one of the knockout mutants he produced showed some symptoms reminiscent of Parkinson's disease - in which the brain's dopamine system is defective."It turned out that one of the brain's dopamine receptors is regulated by an element controlled by retinoic acid," says Chambon. He hopes that such chance findings will become routine if knockouts are screened.

\section{Unrest leads reformer to quit Seoul university's top job}

\section{David Cyranoski, Tokyo}

The president of Korea's largest university has resigned in the face of student unrest and faculty opposition - throwing open to question his plans to turn Seoul National University into an international research powerhouse.

Students and some faculty members had accused Ki-jun Lee of running the university autocratically while maintaining closer links to business than is permitted in Korea. But many scientists and engineers believe he was ousted because his efforts at reform upset some staff, especially in the university's humanities departments.

Instead of completing his four-year term this November, Lee resigned on 1 May and will return to his research in the university's chemical-engineering department.

Student protests against Lee's plans to raise tuition fees and implement other reforms included a 10-day occupation of his office last month. In addition, students and representatives of two faculty associations alleged that Lee had used university funds for private purposes, although his staff say that his expenditures were in line with university policy.

Critics also attacked him for retaining a paid directorship at LG Chemical, a petrochemicals firm. Korean law forbids professors at public universities from accepting payment for work in industry. An official on his staff says Lee did not violate any law, as the money from the directorship

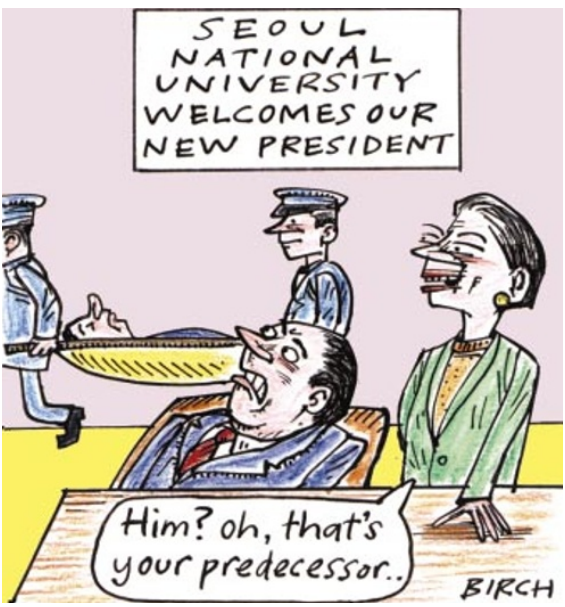

was to support company-related research.

Some university researchers and industry officials say that the main source of opposition to Lee was anxiety among arts professors and some scientists about his reforms. "Professors of basic natural science, humanities and social sciences just didn't like his emphasis on practical sciences and engineering," says one university researcher.

Lee's supporters say that his reforms were working. They claim, for example, that the university has risen substantially in international rankings that measure the number of times its scientific papers have been cited in quality journals.

In Korea, where university presidents usually lack strong executive powers, some fear that the resignation sets a grim precedent for Lee's successor. "The next president will have a difficult time," says the researcher.

"He wanted to remake the tenure system," says the president of a major Korean company who declined to be identified. "He was trying to exercise some muscle, which university presidents don't normally do." 